\title{
Acceptance and Transformation of English Educational Theory in Japan: On Student-Centered Education
}

\author{
Teresa Kuwamura ${ }^{1}$ \\ ${ }^{1}$ Department of English Culture, Faculty of Letters, Konan Women's University, Kobe, Japan \\ Correspondence: Teresa Kuwamura, Department of English Language and Culture, Faculty of Letters, Konan \\ Women's University, 6-2-23 Morikitamachi, Higashinadaku, Kobe, Japan. Tel: 81-78-413-3039. E-mail: \\ teresaldeng@hotmail.com
}

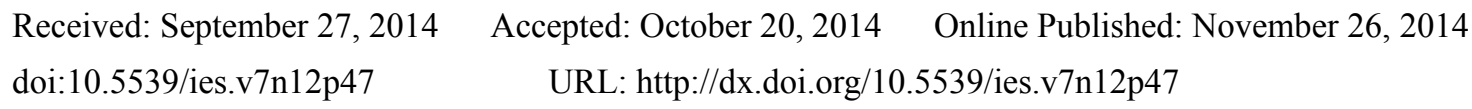

\begin{abstract}
In Japan, various theories and methodologies of English education born in other countries have been practiced, but the result has left a lot to be desired. Still, each theory has its own sociocultural background. When theory goes beyond its culture and locality, it transforms by losing its originality and absorbing new elements from a different sociocultural background. The transformation sometimes happens due to other reasons such as misinterpretation, imprecise translation, etc. In Japan of today, technical terms of pedagogy, such as facilitator, empowerment, and contract, are popular in English education. Those terms were introduced by Carl Rogers, an American humanistic psychologist and educator who established an education theory, Student-Centered Education. Rogers' technical terms as well as his educational theory are often misunderstood or not taken from the full content in Japan. In this essay, I present some examples of common misunderstanding and misuse of Student-Centered Education in Japan caused by scholars' incomplete research, ignoring the difference of the subject such as student's age, impact from Learner-Centered Education, and sociocultural background difference between the U.S. and Japan. It is natural that theory transforms when it reaches to a different environment. If an imported educational theory does not work as expected, it is important to consider the fact that theory may been changed. One needs to examine the reasons why it has deviated from its original principle and adjust the theory when applying it to the student. (Note 1)
\end{abstract}

Keywords: student-centered education, English education, transformation of theory, Japan

\section{Introduction}

In Japan, theories and methodologies of English education born in other countries have been practiced in order to improve student's command of English. They, however, produce poor results, and hence various theories and methodologies have come and gone. Such a rapid change only confuses student. We should remember, however, that each theory and methodology's birth ties to its sociocultural background. For an educational theory, its principle, purpose, methodology, and way to deal with problems in education has to do with its society and culture. Especially in the U. S., an educational theory is created with a deep thinking of improving society. Unlike the rest of the world, educational theory in the U.S. is a way to revolutionize society (Hara et al., 2005, p. 157). When such a theory spreads beyond its social, cultural, and national border, it could lose some of its original elements and even some important essence. To demonstrate what an educational theory could be changed when it reaches a different environment, I use the transformation of Student-Centered Education in Japan as an example. The major reasons that have contributed to the changes are incomplete research, ignoring the difference of the subject such as student's age, impact from Learner-Centered Education, and sociocultural background difference between the U.S. and Japan. This article shall contribute to an argument in Japan regarding whether the pedagogy of Student-Centered Education works or not while the argument has been developed with an unawareness of the transformation of Student-Centered Education.

\section{Acceptance and Transformation}

\subsection{Incomplete Research}

Student-Centered Education is a whole person, or humanistic, education created by Carl Rogers. In the field of English education in Japan, however, Rogers tends to be regarded as one of the creators of humanistic language 
teaching or Learner-Centered Education. For instance, one of the research books on English education in Japan, A comprehensive list of current teaching methods of English edited by Tasaki (2002), states about humanistic education as a basis of humanistic language teaching.

Humanistic Education is an educational reform movement which was advocated in the beginning of 1970s, based on humanistic psychology, idealism, existentialism, interest in human development, counseling, and psychotherapy. (Tasaki, 2002, p. 116. Italics by the author) (Note 2)

However, Rogers, influenced by John Dewey's Child-Centered Education and based on his own psychological theory, Person-Centered Therapy, introduced his new educational theory, Student-Centered Education, in 1940s. In his book published in 1951, he dedicated a whole chapter to Student-Centered Education. That is, his Student-Centered Education is not one of the pedagogies of humanistic education but the basis of the humanistic education.

The book of the Comprehensive List also presented reader incorrect information about Rogers' book and theory, referring to Ayabe's research.

The basic theory of Humanistic Approach which Ayabe has been trying to organize consists of the follows: (1) Need Hierarchy Theory (A. Maslow), (2) actioforma of personality (Yeomans: 1975, Yusuke Kawazu), (3) actioforma of cerebrum (Yusuke Kawazu: 1978), (4) humanistic education (Hiroshi Ito: 1978, G. Moskowitz: 1978), (5) confluent education (G. Brown, B. Galyean: 1977), (6) group dynamics, human dynamics (S. Morel: 1975), (7) humanistic psychology, counseling (C. Rogers, 1967), (8) Others (existentialism, humanitarianism, Zen Buddhism, and so on). (Tasaki, 2002, p. 117. Italics by the author)

The book of The comprehensive list refers to Rogers' book published in 1967 as if Rogers had published his educational and psychological theories for the first time in that year. The research is, however, not complete. Rogers' book published in 1967 is On becoming a person. It is a revised edition of the book published under the same title in 1961. Furthermore, the book is only of a collection of published papers from Rogers.

\subsection{Ignoring the Difference of the Subject}

The introduction of humanistic language teaching in A comprehensive list of current teaching methods of English does not mention the age of the subject. Incomplete research could lead to neglecting the age of the student. In pedagogy, however, the difference of the learners' age is very important to consider. Rogers created his Student-Centered Education for college student and it was under the spotlight in the 1960s when the relationship between teacher and student in college was broken because of student movement and other violations. The relation between teacher and student is a basic infrastructure of education. Teacher had to rebuild the relation with student (Rogers, 1961/1995, p. 293; Kuwamura, 2010, pp. 30-34). That's why Rogers' Student-Centered Education was on spotlight because the key of the educational theory is to listen to others and understand them from their own internal framework of references in order to let them open to each other, in other words, to make them "a fully-functioning person" (Rogers, 1959, pp. 184-256). This means Rogers denied one-way teaching by teacher.

Ignoring of the difference of the subject leads to another criticism to Student-Centered Education in Japan. I often find that books which criticize Student-Centered Education and Learner-Centered education do not consider the academic level of student because the pedagogies argue for student's free choice of educational themes and materials. As pointed out earlier, however, Student-Centered Education was created for college student, or people who have already had basic academic knowledge. That's the reason Rogers allowed students to choose something interesting for themselves as educational materials.

It is also incorrect to conclude that Rogers only gave students something that they were interested in. Student-Centered Education is famous in terms of its flexibility. In Japan, many people seem to misunderstand that Student-Centered Education is characteristic for student's autonomous and free will to learn and teacher's supporting and facilitating role, or a matter of positional relation in education. The key point of Student-Centered Education is that from the standpoint of a whole person, teacher always analyzes learning from student's internal framework of reference, such as logic, emotion, and so on, with listening to student's voice, no matter what kind of pedagogies teacher uses. In addition, though Student-Centered Education was, as mentioned earlier, created 
for college student, student's academic levels are different. Carl Rogers used different pedagogies according to the level of the students, according to the explanation from Natalie Rogers, Carl Rogers' daughter and collaborator, from my interview with her at her home in Sebastopol (Kuwamura, 2010, pp. 167-178). Furthermore, she said,

\begin{abstract}
"We should not confuse the diversity of education with the diversity of students; based on development of a whole person with consideration of student's internal framework of reference, we should use teacher-centered class and student-centered class due to educational contents. For example, regarding a basic formula and knowledge, teacher should make student memorize them, give them tests, and evaluate them. Additionally, teacher should relate to student in a natural way of a person; when teacher feels reluctant, they can honestly speak it out to student. It is effective for student's acceptance of teacher as a person. The most important point is, that teacher should not be meaninglessly authoritative but be honest to student as a person and always understand student from their internal framework of reference, and that Student-Centered Education should be an education based on developing student as a whole person as an integration of emotion and intelligence" (Kuwamura, 2010, pp. 172-173).
\end{abstract}

The flexibility of Student-Centered Education allows the educational theory to be used for student younger than college student. Still, teacher should pay attention to what Natalie pointed out about teacher's role and attitude to student.

Regarding neglect of the difference of student's age, the word "student" also could create issues. The meaning of the "student" in Student-Centered Education is college student. This word, hence, should be translated as “gakusei” (学生), which is a Japanese word for college student. I sometimes encounter the translation "seito chūshin kyōiku” (生徒中心教育); “seito" (生徒) means junior high school and high school student and "chūshin kyōiku" (中心教育) is “-centered education." Both "gakusei" and "seito" are "student" in English, but the meanings of "gakusei" and "seito" are different. If the words are not chosen properly, it would cause confusion. This is not the issue of direct translation but the problem of ability to choose the most appropriate word in Japanese. When the word "student" is translated to "seito," it naturally leads to the issue that teacher even lets junior high or high school student freely choose the educational materials according to their own interest. In the case, teacher cannot guarantee the level of their academic ability. In addition, such a "student-centered" education could be criticized for the reason that the pedagogy facilitates "narcissism," as the book $A$ comprehensive list of current teaching methods of English describes as follows,

Narcissism: This approach gives weight to activity of self-contemplation, and hence has intense interest in "self," but lack interest in Others (Tasaki , 2002, p. 124).

This contradicts to Rogers' educational theory; the core of the theory is for fostering a fully-functioning person, a person who is open to other people. (Note 3)

\title{
2.3 Impact from Learner-Centered Education
}

Similar to the last section, the name of "Gakushūsha-chūshin kyōiku" (学習者中心教育: Learner-Centered Education) also could hide the age of learner. In Japan, this pedagogy stems from Charles A. Curran's "Community Language Learning." This is a methodology for French education and it is for student at community college or adult. (Note 4) In addition, Curran used Rogers' technical terms, such as facilitator, contract, empowerment, etc., without any reference to Rogers. Curran created a totally different pedagogy. (Note 5) Curran's "Community Language Learning" is simply a second language teaching theory based on the belief that student must improve their ability of second language because they want to become a person like their teacher (Curran, 1972, p. 92). The final stage of language teaching in Curran's theory is that student becomes teacher. There is no gap between teacher and student. Teacher has no authority in a classroom and hence Curran called his own theory Learner-Centered Education (Curran, 1972, p. 101). Curran's theory is on the basis of an existed ideal relation between teacher and student. In Japan of today, it is questionable how many students want to become like their teachers and how many teachers can expect an ideal good relation with student. As Satoshi Tanaka points out, relationship between teacher and student as an infrastructure of education in Japan has been broken (Tanaka, 2003, p. 265). The situation requires teacher to find an idea and a practice to build up a good relation with student. Curran's pedagogy, hence, does not work in Japan as well as his book says. Curran wrote 
his pedagogy in his book based on his theory for teaching language and was introduced to Japan. As a result, technical terms created by Rogers lost its significance in language teaching theory in Japan, while Rogers' theory became known by way of some characteristic pedagogies, such as Suggestopedia and pedagogies like occult. (Note 6)

\subsection{Sociocultural Background Difference between the U.S. and Japan}

As mentioned earlier, Rogers' Student-Centered Education was under the spotlight in the 1960s when the relation as an infrastructure of education between teacher and student in college was broken because of student movement and other violations. In Rogers' mind, this phenomenon stemmed from a certain situation which he had recognized as peculiar to American society and hence he wrote his educational theory in 1951. It was a paternalistic society on the basis of Protestantism. In order to change such a society through education, Rogers created Student-Centered Education (Rogers, 1969, pp. 105-106).

Student-Centered Education was created based on Rogers' own psychological theory, Person-Centered Therapy. Rogers saw a paternalistic character in counselling by Freudian psychoanalysts as well, which was popular at that time. Rogers leveled two critiques against Freudian psychoanalysts, their dogmatism to Freudian theory and their tendency to try to understand a patient in the framework of the theory (Kuwamura, 2010, p. 15; Rogers, 1959, p. 191). Rogers, who valued clinical practice more than theory, thought "blind adoration of theory could lead to the distortion of the reality of a patient by adjusting this reality to the theory without any review of the problems in its theoretical disadvantages in principle" (Kuwamura, 2010, p. 15; Rogers, 1959, p. 191). Rogers, hence, insisted on listening to the patient's voice and empathizing the patient from the perspective of his or her own feeling and logic, or from his or her internal framework of reference. By doing that, instead of judging the patient's mental condition by imposing a theoretical framework, one can understand the facts of the patient's suffering.

This method is for fighting against paternalistic society in America, as well. "Paternalism is a protective stance for others: On a benevolent basis, someone intervenes in a situation that a person cannot handle for himself or herself, in the same way parents approach their child. The reason why paternalism is sometimes criticized is that it authoritatively takes a right of self-decision" (Kuwamura, 2010, p. 264). "Against authoritative paternalism and for a democratic society, Rogers insisted on sharing authority and making an individual decision autonomously and initiatively" (Kuwamura, 2010, p. 264). In order to practice this, Rogers emphasized emphatic understanding of others' internal framework of reference.

In the U.S. psychoanalysis, which takes a notice of Oedipus complex, or collision with Father, functions as a buffer for people living in the paternalistic, competitive society and to facilitate their adjustment to the society because the U.S., unlike countries of Catholicism, has no social mechanism as redemption and acceptance. Rogerian hearkening to others' voice, empathic understanding of others, and its practice, therefore, have a social meaning of counter-argument of traditional authority, or authoritarian paternalism of secular Protestantism and a meaning of a new buffer for American people (Kuwamura, 2010, pp. 264-265; History of Educational Thought Society, 2000, p. 730). By his theory and practice, Rogers showed how people should live democratically (Kuwamura, 2010, p. 265). It is a fight against and an attempt of revolution of American society.

On the other hand, in Japan, when Rogers' educational theory was introduced in 1970s, it was expected as a theory for developing a harmonious relationship with others in society peculiar to Japan, or "rural society." Rogers' theory was not used to fight against Japanese paternalistic society, nor revolutionize society, but facilitate good human relationship in "I-jump-into-the-sea-because-everybody-does" society and contribute to strengthening Japanese paternalistic society. As one of the disadvantages of Student-Centered Education that is often pointed out, the pedagogy tends to force student to make an individual decision autonomously and speak it out initiatively. As the book A comprehensive list of current teaching methods of English denotes,

Operationism: Student is used to following teacher's direction, and hence student is forcibly made to involve the activity of self-expression without readiness (Tasaki , 2002, p. 125).

The criticism like that, however, has no meaning because Student-Centered Education went beyond American national border into Japan, with its significance in principle undercut.

\section{Conclusion}

It might be impossible to reintroduce the authentic Rogers' Student-Centered Education in Japan. In his study of 
world literature, Franco Moretti, who has a bird's eye view of literature in the world with reference to Immanuel Wallerstein's World-Systems Theory and Frederic Jameson's law of literary evolution, states that literature in an area has been developed as a compromise between the local styles of peripheral countries and the metropolitan culture of core countries in Europe (Moretti, 2000, p. 54). It is true to English educational theory as well. As long as theory goes beyond its original cultural and national border, it is natural that theory transforms. If an educational theory imported from another area does not work better than expected, it is important to realize the fact that theory may has been changed and therefore consider the process and reasons of transformation and its original principle. Also, it is important to adjust the theory based on the subject. Even if theory is changed, it can still be useful. For example, Student-Centered Education is valuable for Japanese school where many students keep off from others and teachers. A theory and a methodology are not a panacea that can be applied to any areas. In addition, every theory and every methodology has advantage and disadvantage. One cannot emphasize the advantage only. Student can be considered as a socio-cultural agency. One needs to adjust a theory and create a better approach with the support of the adjusted theory and methodology. Eyes on globalism and localism are important. In short, if some theory does not work well, one should not simply claim that it is not effective, without considering the original principle and significance and the process of acceptance and transformation.

\section{References}

Curran, C. A. (1972). Counseling learning: A whole person model for education. New York: Grune and Stratton.

Hara, K., Yamanouchi, K., \& Sugimoto, H. (Eds.). (2005). Comparative sociology of education (Kyōiku no hikaku shakaigaku). Tokyo: Gakubunsha.

History of Educational Thought Society. (Ed.). (2000). Encyclopedia of educational thought (Kyōiku shisō jiten). Tokyo: Keisō Shobō.

Kuwamura, T. (2008). Dewey's "Child-Centered Education" and Rogers' "Student-Centered Education" (Dyūi no "jidō chūshin kyōiku" to Rojāzu no "gakusei chūshin kyōiku"). Bulletin of Dewey society of Japan, 49, $33-42$.

Kuwamura, T. (2009). Carl Rogers' "Student-Centered Education" and Charles A. Curran's "Learner-Centered Education." (Rojāzu no "gakusei chūshin kyōiku" to Karan no "gakusyūsya chūshin kyōiku"). Transactions of English studies and English teaching, 14(28), 1-14.

Kuwamura, T. (2010). On theoretical application and its practice of C. Rogers's "Student-Centered Education" in foreign language education (Gaikokugo kyōiku ni okeru C. Rojāzu no "gakusei chūshin kyōiku" no rironteki tenkai to jissen) (Unpublished Ph.D. dissertation, Nara Women's University).

Moretti, F. (2000). Conjectures on world literature. New Left Review, 1, 54-66.

Rogers, C. (1959). A theory of therapy, personality, and interpersonal relationships, as developed in the client-centered framework. In K. Sigmund (Ed.), Psychology: A study of a science, vol.3. Formations of the person and the social context (pp. 184-256). New York: McGraw-Hill.

Rogers, C. (1961/1995). On becoming a person: A therapist's view of psychotherapy. New York: Houghton Mifflin.

Rogers, C. (1969). Freedom to learn: A view of what education might become. Columbus: Charles E. Merrill.

Tanaka, S. (2003). From pop sensibility to floating sensibility: Disharmony in Japanese educational system (Poppukankaku kala huyū kankaku e: Shisutemu ni hibiku fukyō waon"). In H. Morita, N. Morita, \& Y. Imai (Eds.), Education and politics: Rereading of history of education after World War Two (Kyōiku to seiji: Sengo kyōikushi wo yominaosu, pp. 250-281). Keisō Shobō.

Tanemura, A., \& Miura T. (2011). The main current of humanistic language teaching and its contemporary significance. Bulletin of faculty of education, Shizuoka University. Kyoka kyoiku series, 42, 83-117.

Tasaki, K. (Ed.). (2002). A comprehensive list of current teaching methods of English (Gendai eigo kyōjyuhō sōran). Tokyo: Taishukan.

\section{Notes}

Note 1. This paper is based on the manuscript of my presentation titled as "Acceptance and transfiguration of English educational theory in Japan" in the symposium "East-West studies: Literature, thoughts, linguistics, English education" (Symposium in the conference of the 50th anniversary of the foundation of the Katahira association of British and American literature, co-hosted by Global symbiotic research center at Nagoya Institute 
of Technology) at Nagoya Institute of Technology on August 3, 2014.

Note 2. All quotations from books and papers in Japanese are translated by the author.

Note 3. Ignoring the difference of the subject such as students' age might also bring confusion when applying Dewey's educational theory Child-Centered Education and Rogers' Student-Centered Education. Those two theories look similar with each other in terms of denial of one-way teaching by teacher. Dewey's theory, however, emphasizes experience of young students and their socialization, while Rogers' theory emphasizes understanding already-socialized-to-some-degree- student's internal framework of reference to let them open more to others to be a fully-functioning person. For reference, Dewey's education, on which Rogers' created his own educational theory, focused the interaction between student and society in society with strong social norm, while Rogers' educational theory focused on the inner world of student in society with weak social norm. In a society of weak social norm like Japan, it is important to develop the ability of self-decision, being fully open to a rapidly changing world. See, Kuwamura (2008).

Note 4. See, Curran's Counseling learning.

Note 5. See, Kuwamura (2009).

Note 6. See, Tanemura \& Miura (2011).

\section{Copyrights}

Copyright for this article is retained by the author(s), with first publication rights granted to the journal.

This is an open-access article distributed under the terms and conditions of the Creative Commons Attribution license (http://creativecommons.org/licenses/by/3.0/). 